Jacek Jędrysiak

https://orcid.org/0000-0002-5472-136X

Instytut Historyczny Uniwersytetu Wrocławskiego

\title{
Kadra oficerska Legionów Polskich w ocenie niemieckich doradców z marca 1917 r.
}

W mowie wygłoszonej na Zamku Królewskim w Warszawie 15 XII 1916 r. generalny gubernator warszawski Hans Hartwig von Beseler w sposób jasny i jednoznaczny wyraził swój stosunek do Legionów Polskich. „Myślą niektórzy, że stworzenie armii jest rzeczą łatwą i prostą. [...] Armia nie jest skupieniem masy ludzkiej, jest to organizm delikatny, który zorganizowany być musi aż do najdrobniejszych szczegółów, który musi być zaopatrzony w mnóstwo najrozmaitszych właściwości technicznych, jeżeli odpowiedzieć ma zadaniu. Dla stworzenia takich armii nie starczy garstka patriotycznej młodzieży, która sądzi, że na tem koniec, gdy broń weźmie na ramię i pomaszeruje

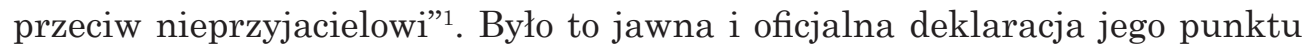
widzenia, wyrażanego wcześniej w poufnych meldunkach ${ }^{2}$. Wbrew temu głęboko ugruntowanemu przeświadczeniu, okoliczności zmusiły niemieckiego generała do ścisłej współpracy z kadrami utworzonego 20 września przez cesarza Franciszka Józefa Polskiego Korpusu Posiłkowego (PKP) ${ }^{3}$. Fiasko

\footnotetext{
${ }^{1}$ Archiwum Główne Akt Dawnych (dalej: AGAD), 531: Cesarskie Generalne Gubernatorstwo Warszawskie (dalej: CGGW), 49, Mowa Jenerał-Gubernatora von Beselera. Warszawa, Zamek dnia 15 XII 1916 r. [Stenogram urzędowy, przekład uwierzytelniony], s. 6-7.

${ }^{2}$ Beseler Denkschift vom 23.7.1916, oprac. H. Lemke, „Jahrbuch für Geschichte der UdSRR und der Volksdemokratischen Länder Europas" 1960, s. 390-400; J. Stachiewicz, Niemieckie plany organizacji Wojska Polskiego w czasie I wojny światowej, „Niepodległość” 1930, t. I, z. 1, s. 24-27.

${ }^{3}$ Zob. W. Conze, Polnische Nation und deutsche Politik im Erste Wetlkrieg, Köln-Graz 1958, s. 215, 217-220; H. Lemke, Allianz und Rivalität. Die Mittelmächte und Polen im
} 
ogłoszonych na kanwie Aktu 5 listopada odezwy ${ }^{4}$ i przepisów werbunkowych ${ }^{5}$ wymusiło modyfikację decyzji podjętych w Pszczynie na początku tego miesiąca $^{6}$. O ile wówczas niemieckie Oberste Heeresleitung (OHL) raz jeszcze skutecznie zablokowało koncepcję wykorzystania PKP jako rdzenia kadry kursów wyszkoleniowych dla późniejszej Polnische Wehrmacht (PW), o tyle w myśl zawartego 11 XI 1916 porozumienia ${ }^{7}$ PKP winno zostać przekazane pod komendę Beselera jako zaczątek formowanej armii. Korpus miał jak najszybciej zostać wydzielony z armii cesarsko-królewskiej, a termin przekazania po komendę niemiecką ustalono ostatecznie na 10 IV 1917 r.

Proces formowania PW zakładał utworzenie liczacej 100 tys. żołnierzy armii, zorganizowanej w cztery dywizje ${ }^{8}$. Nadzór nad procesem jej kształcenia powierzono inspektorowi kursów wyszkolenia (Inspekteur der Ausbildungkurse $)^{9}$, którym 21 XI 1916 r. mianowano saskiego gen. piechoty Felixa Bartha ${ }^{10}$. Zgodnie $\mathrm{z}$ otrzymanym zadaniem ${ }^{11}$ przedstawił on plan obliczonego na 10 tygodni procesu wyszkolenia polskiej kadry oficerskiej celem uzyskania przez nią elementarnej zdolności samodzielnego szkolenia rekrutów ${ }^{12}$. W związku z tym poszczególnym pułkom PKP przydzielono niemieckich oficerów jako doradców, faktycznie kierujących procesem szkolenia ${ }^{13}$.

erste Weltkrieg (bis zur Februarrevolution), Berlin 1977, s. 357-358; M. Szymczak, Między Habsburgami a Hohenzollernami. Rywalizacja niemiecko-austro-węgierska w okresie I wojny światowej a odbudowa państwa polskiego, Kraków 2009, s. 209-211.

${ }^{4}$ AGAD, CGGW, 35, Do ludności Jeneralnych Gubernatorstw warszawskiego i lubelskiego, Warszawa i Lublin 9 XI 1916 r., s. nlb.

${ }^{5}$ Ibidem, 37, Przepisy dotyczące dobrowolnego wstępowania do wojska polskiego, Warszawa 12 XI 1916 r., s. nlb.

${ }^{6}$ Ibidem, 82, [Odpis ustaleń z Pszczyny], Pszczyna 3 XI 1916 r., s. 25-26.

${ }^{7}$ Centralne Archiwum Wojskowe Wojskowego Biura Historycznego (dalej: CAW WBH), Komenda Legionów i Dowództwo Polskiego Korpusu Posiłkowego (dalej: KLiDPKP), I.120.1.4, Vereinbarungen über Verwertung der polnischen Legion, [16 XI 1916 r.], k. 186-187.

${ }^{8}$ Dokładnie 4 dywizje z 12 pułków, 36 kompanii ckm, 8 szwadronów, 4 kompanie sanitarne, 4 sztaby dywizjonów, 12 kolumn amunicyjnych, 12 kolumn taborowych, 8 lazaretów polowych i 4 piekarnie polowe. AGAD, CGGW, 82, Pismo nr 1557 geh. Oddziału Ib sztabu CGGW, Warszawa 25 X 1916 r., s. 17-19. Zob. też: J. Jędrysiak, D. Koreś, Realizm czy fantazja? Plany rozbudowy i reorganizacji Legionów Polskich od 1916 r. do kryzysu przysięgowego (lipiec/sierpień 1917 r.) z perspektywy polskiej i niemieckiej, w: Mało znana I wojna światowa. Studia i szkice do dziejów Wielkiej Wojny na froncie wschodnim, t. II, red. A. Smoliński, Grajewo 2018, s. 183-250.

${ }^{9}$ CAW WBH, KLiDPKP, I.120.1.4, Pismo AOK Op. Nr 33.600, Zusammenstellung der Vereinbarungen zwischen der deutschen Obersten Heeresleitung und dem k.u.k Armeeoberkommando über das polnische Heer, [16 XII 1916 r.], k. 204-205.

${ }^{10}$ Ibidem, I.120.1.111, Kriegstagebuch der Insp. d. Ausb. Wesens vom. 1. Jan. bis 1. Okt. 1917, k. 2.

11 AGAD, CGGW, 83, Projekt pisma Abt. Po 1 nr 206 Szefa Abteilung Polnische Wehrmacht, Warszawa 2 XII 1917 r., s. 106.

12 CAW WBH, KLiDPKP, I.120.1.111, Kriegstagebuch der Insp. d. Ausb. Wesens vom. 1. Jan. bis 1 . Okt. 1917, k. 8.

${ }^{13}$ Ibidem, I.120.1.5, Anweisung für die Umbildung und Umbewaffnung der polnischen Legion unter Berücksichtigung deutscher Verhältnisse, Warszawa 10 XII 1916 r., k. 69-70. 
Pierwsza faza edukacji miała trwać od 15 XII 1916 r. do 31 I 1917 r. ${ }^{14}$ Jednak treść napływających raportów skłoniła Bartha do zarządzenia już 3 I 1917 r. zainicjowania tydzień później specjalnych zajęć celem podniesienia poziomu wykształcenia polskich oficerów ${ }^{15}$. Ponadto do 1 II 1917 r. Komenda PKP miała przedstawić inspektorowi po dwóch oficerów z każdego pułku, przeznaczonych do dalszego szkolenia jako przygotowania na kursie Sztabu Generalnego i adiutantury celem dalszej służby w sztabach wyższych. Kurs ten zapowiedziano na okres od 1 do 28 II 1917 r. w Warszawie i wybrano nań łącznie 22 oficerów ${ }^{16}$.

Już 2 I 1917 r. legionowe pułki piechoty przetransportowano do obozów ćwiczebnych w Zambrowie (1 i 2 Pułk Piechoty), Zegrzu (3 i 4 pp), Ostrowie (5 pp) i Dęblinie (6 pp). Oba pułki kawalerii pozostały odpowiednio w Ostrołęce i Mińsku Mazowieckim, tabory w Warszawie, a służby techniczne w Modlinie. Artylerzystów szkolono w Rembertowie ${ }^{17}$. W połowie stycznia 1917 r. Inspektor złożył na ręce Beselera raport jednoznacznie wskazujący na trudności w realizacji planu szybkiego uzyskania gotowości przez pierwsze polskie oddziały ${ }^{18}$. Zamierzenie OHL, by w połowie kwietnia wysłać na front choćby część polskich dywizji, było nierealne. Kolejny raport, z końca stycznia, zawierał tożsame przekonanie $\mathrm{w}$ tej materii ${ }^{19}$. Barth zauważał wprawdzie żywe zainteresowanie polskich oficerów procesem przeszkolenia, podkreślał jednak równocześnie brak wytrwałości w realizacji tego celu, szczególnie wśród młodszych oficerów. Starsi nie mieli z kolei dostatecznego wpływu na podwładnych. Problemy sprawiali także byli oficerowie austriaccy, niechętnie wyzbywający się swoich nawyków i utrudniający pracę doradcom. Barth

${ }^{14}$ Ibidem, Program szkolenia Polskiego Korpusu Posiłkowego wedle wzorów niemieckich [Załącznik do pisma z 10 XII 1916 r.], k. 73-74.

15 Ibidem, Pismo nr 321 Inspektora Kursów Wyszkolenia, Warszawa 3 I 1917 r., k. 89-90.

16 Ibidem, Pismo Komendy Legionów nr 516/3, Warszawa 27 I 1917 r., k. 208-209; ibidem, I.120.1.363, Lista oficerów Szkoły Sztabowej w dniu 20 II 1917, k. 309. Na temat terminu kursu oraz liczby i listy uczestników przed laty doszło do sporu związanego z publikacja Juliana Bugajskiego. Idem, Wojenna Szkoła Sztabu Generalnego - pierwsza uczelnia wojskowa II Rzeczypospolitej, „Wojskowy Przegląd Historyczny” 1967, nr 1 (41), s. 209-210; J. Ciałowicz, W sprawie Wojennej Szkoty Sztabu Generalnego wyjaśnienia, uzupetnienia i sprostowania, „Wojskowy Przegląd Historyczny” 1967, nr 4 (44), s. 456-459; J. Rzepecki, Przyczynek do Dziejów Wojennej Szkoty Sztabu Generalnego, „Wojskowy Przegląd Historyczny" 1967, nr 2 (42), s. 465-466. Na temat założeń i przebiegu kursu zob. J. Jędrysiak, Dtuga droga do odrodzenia - koncepcje budowy polskich władz wojskowych pod okupacja niemieckq $w$ latach 1916-1918, „Przegląd Historyczno-Wojskowy” 2018, nr 1-2 (262-263), s. $70-75$.

${ }^{17}$ CAW WBH, KLiDPKP, I.120.1.111, Kriegstagebuch der Insp. d. Ausb. Wesens vom. 1. Jan. bis 1. Okt. 1917, k. 14-15. Zob. też: Z. Moszumański, Z. Kozak, Wojenne szkoty dla oficerów artylerii (1914-1921), Pruszków 2002.

18 AGAD, CGGW, 82, Raport Inspektora Wyszkolenia PSZ, Warszawa 15 I 1917 r., s. 34-36.

${ }^{19}$ CAW WBH, KLiDPKP, I.120.1.111, Pismo Inspekcji Wyszkolenia Tagebuch-Nr. 51 geh., Warszawa 31 I 1917 r., k. 154-164. 
z uznaniem konstatował wyższy niż w innych formacjach stopień nasycenia Legionów przedstawicielami inteligencji, co sprzyjać miało przyswajaniu nowinek. Jednocześnie akademickie wykształcenie sporej części oficerów powodowało u nich wzmożoną chęć dokształcania się w dziedzinie naukowej, przy zaniedbywaniu praktyki.

W swych opiniach Barth bazował na raportach przesyłanych mu przez kierowników Komend Wyszkolenia. Część z nich zachowała się w teczce o sygn. 1.121.236 w zespole Polskiej Siły Zbrojnej przechowywanym w zasobie Centralnego Archiwum Wojskowego Wojskowego Biura Historycznego im. gen. broni Kazimierza Sosnkowskiego. Jest ona tylko częściowo sfoliowana, do karty 54, gdzie znajduja się raporty z grudnia 1916 i stycznia $1917 \mathrm{r}$. Kolejna grupa materiałów stanowi efekt rozkazu zobowiązującego wszystkie niemieckie komendy (poza artyleria ${ }^{20}$ ) do przesłania do 28 stycznia raportów na temat stanu wyszkolenia oddziałów polskich, w tym szczególnie użycia broni, marszów, strzelań, ćwiczeń marszowych i nocnych ${ }^{21}$. Prawdopodobnie proces ten powtórzono dwa tygodnie później i stał się on podstawą raportu Bartha z 17 II 1917 r. $^{22}$, dotyczacego przede wszystkim stanu wyszkolenia rekrutów. Kolejna grupa sprawozdań, będąca obiektem edycji, powstała na podstawie rozkazu z 1 III 1917 r. (Dziennik nr 89 pers.) ${ }^{23}$. Barth polecał Komendom Wyszkolenia dokładne opisanie procesu szkolenia i nastrojów w oddziałach, a także ocenę polskiego korpusu oficerskiego, zwłaszcza pod kątem postrzegania obowiązków służbowych oraz wskazanie oficerów zdatnych do pełnienia funkcji komendantów pułków i batalionów. Większość niemieckich doradców wywiązała się z tego zadania, dzięki czemu powstał unikalny materiał pozwalający spojrzeć oczami niemieckich „sojuszników” na poszczególne postacie w kadrze legionowej. Obiektem, nieraz brutalnej oceny, stało się wielu znanych i zasłużonych polskich oficerów, w tym późniejszych generałów.

Oczywiście opinii tych nie należy traktować bezrefleksyjnie. Niemieccy oficerowie patrzyli na sprawę przez pryzmat swojej wiedzy i wyszkolenia, które niekoniecznie były adekwatne do porządków w ochotniczej formacji. Zszokowało ich także skonstatowanie, że po wieloletniej służbie znajdowali się

${ }^{20}$ Skład polskiej artylerii ustalono na 18 baterii dział polowych i 12 baterii haubic wydzielonych z armii niemieckiej oraz 15 baterii polskich. AGAD, 531: CGGW, 82, Pismo Abteilung Polnische Wehrmacht nr $34 \mathrm{w}$ sprawie kursów wyszkoleniowych polskiej artylerii polowej [koncept], Warszawa 3 XII 1916 r., s. 40-41; ibidem, Pismo Abteilung Polnische Wehrmacht nr 163 P2 do Ministerstwa Wojny [odpis], 10 XII 1916 r., s. 44.

${ }^{21}$ CAW WBH, Polska Siła Zbrojna (dalej: PSZ), I.121.1.236, Bericht über den Stand des Ausbildung der poln. Truppen [Projekt], Warszawa 20 I 1917 r., k. 45.

${ }^{22}$ CAW WBH, KLiDPKP, I.120.1.111, Raport Inspektora Wyszkolenia PSZ, Warszawa 17 lutego 1917 r., k. 165-167.

${ }^{23}$ CAW WBH, PSZ, I.121.8.8, Rozkaz Inspekcji Wyszkolenia Tageb.-Nr. 89 pers., Warszawa 1 III 1917 r., s. nlb. 
w randze równej lub niższej niż niejednokrotnie „młodociani” polscy dowódcy. Co więcej, ci wcale nie patrzyli na swoich doradców z podziwem, przedkładając swe doświadczenia frontowe nad umiłowanie służby swych często leciwych pomocników, z których część była wiekowymi oficerami rezerwy. Swoją rolę odgrywały także stereotypy. W pełni znajdowały tu zatem odzwierciedlenie zamieszczone na wstępie słowa Beselera, pokazujące, że mimo „sojuszu” cele polskie i niemieckie były już w tym czasie zupełnie rozbieżne.

$$
* * *
$$

Przedstawiane materiały to wybór fragmentów rękopiśmiennych raportów z marca 1917 r., zebranych we wspomnianej teczce $\mathrm{nr}$ 1.121.236. Nie stanowiły one obiektu analiz ${ }^{24}$ lub edycji. Są one niepaginowane, część z nich to zapewne odpisy, sporządzone trudnym do odczytania ołówkiem kopiowym. Materiały zostały spisane w języku niemieckim, pismem odręcznym, alfabetem neogotyckim. Prezentowane tłumaczenie jest mojego autorstwa, starałem się w nim oddać styl wypowiedzi poszczególnych oficerów, zachowałem także stosowane przez nich skróty. Z tego względu w niektórych miejscach czytelnik z łatwością dostrzeże ślady specyfiki niemieckiej składni. Do edycji ze względów objętościowych wybrałem tylko fragmenty dotyczące ocen oficerów, w tym zwłaszcza te mające charakter personalny. W przyszłości planuję prezentację pełnej treści tych raportów, przy okazji prac nad monografią PW.

W odniesieniu do powszechnie znanych postaci opracowanie zostało ograniczone do najważniejszych elementów, głównie ich identyfikacji i wskazania adresów bibliograficznych. Szczegółowe biogramy zamieściłem tylko w wypadku oficerów mniej rozpoznawalnych. Bardzo przydatna w tej materii okazała się baza „Żołnierze Niepodległości”, dostępna na stronie Muzeum Józefa Piłsudskiego w Sulejówku ${ }^{25}$. Szczątkowe informacje dotyczące oficerów niemieckich pochodzą z zachowanych wykazów dostępnych w zespole Komendy Legionów Polskich ${ }^{26}$.

$$
* * *
$$

${ }^{24}$ Materiał wspominany: J. Jędrysiak, Stużba i sita Polnische Wehrmacht, „Polska Zbrojna Historia" 2018, nr 4, s. 34.

${ }_{25}$ Zob. https://zolnierze-niepodleglosci.pl/start/ (dostęp: 18 IV 2020).

${ }^{26}$ CAW WBH, KLiDPKP, I.120.1.346b, Pismo Komendy Legionów nr OP 686/9 do Inspektora Wyszkolenia PSZ, Warszawa 13 XII 1916 r., k. 552-615. 
Warszawa, 7.3.1917

\author{
Sprawozdanie \\ wg. [Rozkazu] Inspektoratu z 1.3.1917 Dziennik nr 89 pers.
}

$[\ldots]$

Korpus oficerski prezentuje z nielicznymi wypadkami wielką pasję, jednak oficerom brakuje prawie bez wyjątku wprawy w dowodzeniu, szkoleniu i wychowaniu żołnierzy. Poziom rozumienia obowiązów służbowych mógłby nadal zostać wydatnie podniesiony. $\mathrm{W}$ interesie ich własnego wykształcenia oficerowie powinni bardziej dbać o pełnioną służbę i odbywać ją samodzielnie, tym bardziej, że najczęściej w każdej kolumnie jest ogólnie tylko jeden oficer a wykształcony personel szkoleniowy nie jest dostępny, wzgl. nie był dostępny do tej pory. Niemal wszyscy oficerowie byli dotąd zupełnymi laikami w zakresie szkolenia rekrutów. [...] Ze znanych mi oficerów podporucznik Tyrpa ${ }^{27}$, dowódca kolumny sprzętu saperskiego ${ }^{28}$, wyróżnia się szczególna pilnością i wielką rozumnością oraz zapowiada się na przyszłego dobrego oficera szkoleniowego. Także podporucznik Czopp ${ }^{29}$, dowódca kolumny amunicyjnej 2 w Retkini, robi wrażenie bardzo sprawnego i wygląda, że dobrze trzyma w ręce swoją kolumnę. Wedle doniesień rotmistrza Materne ${ }^{30}$ także porucznik Wilk ${ }^{31}$, dowódca kolumny prowiantowej 3 , powinien być w przyszłości całkiem

${ }^{27}$ Rudolf Tyrpa (1891-1971) - żołnierz i dowódca kolumn taborowych i prowiantowych Legionów Polskich (LP), ppor. od 1 XI 1916 r. Po kryzysie przysięgowym pozostał w PKP. Od 1918 r. w Wojsku Polskim (WP). Przeniesiony do rezerwy 23 V 1923 r. w stopniu rtm. Zob. https://zolnierze-niepodleglosci.pl/\%C5\%BCo\%C5\%82nierz/229356/ (dostęp: 18 IV 2020).

${ }^{28} \mathrm{~W}$ oryginale Schanzzeugkolonne.

${ }^{29}$ Wilhelm Czopp (1891-1968) - od 1912 r. członek Związku Walki Czynnej (ZWC) i Związku Strzeleckiego (ZS), następnie żołnierz 1 i 6 pp LP, w styczniu 1916 r. przeniesiony do 1 pa, gdzie dowodził kolumną amunicyjna. Wedle zachowanych materiałów awansowany na ppor. dopiero 1 IV 1917 r. Po kryzysie przysięgowym w PKP. Po 1918 r. osiagną stopień płk dypl., w 1939 r. dowódca 5 Pułku Artylerii Ciężkiej, następnie przebywał we Francji i Wielkiej Brytanii. Zob. https://zolnierze-niepodleglosci.pl/\%C5\%BCo\%C5\%82nierz/187384/ (dostęp: 18 IV 2020).

${ }^{30}$ [Imię nieznane] Materne - rotmistrz rezerwy (od 15 II 1915 r.), ostatni przydział Inspekcja Etapowa Woyrscha.

${ }^{31}$ Rudolf Wilk (1879-1941) - od 1911 działacz ZWC i ZS, następnie żołnierz 1 pp LP. Od 2 VII 1915 por. tab. i dowódca komp. Następnie w PW i PKP. Uczestnik wydarzeń pod Rarańczą w 1918 r., sądzony w procesie o zdradę. Członek Polskiej Organizacji Wojskowej (POW), uczestnik powstania wielkopolskiego i wojny polsko-bolszewickiej. Od $1925 \mathrm{w}$ st. sp. w randze mjr. Zob. https://zolnierze-niepodleglosci.pl/\%C5\%BCo\%C5\%82nierz/231658/ (dostęp: 18 IV 2020). Zob. też: J. Magdoń, „Stawa Wilka”. Major Wtadysław Rudolf Wilk - Komendant Okregu III (Rzeszowskiego) Zwiazku Strzeleckiego, w: Bohaterowie i duma. 100-lecie Zwiazku Strzeleckiego w Rzeszowie, red. G. Ostasz, W. Paruch, J. Magdoń, Rzeszów 2014. 
dobrym oficerem, dlatego też przekazano mu szkolenie rekrutów kolumn zaopatrzeniowych skoncentrowanych we Włocławku. Pozostali oficerowie muszą się uczyć od swoich polskich przełożonych jak jeszcze bardziej niż dotychczas aktywnie uczestniczyć w służbie, samodzielnie dowodzić i szkolić oddziały oraz nie pozostawiać szkolenia rekrutów swym podwładnym. [...]

$\mathrm{Na}$ stanowisko komendanta batalionu, tzn. jako komendanta dywizjonu ${ }^{32}$ $\mathrm{w}$ kolumnach amunicyjnych i taborach, wchodzi w rachubę przede wszystkim kapitan Passella ${ }^{33}$. Ten jest ob. komendantem taborów polskich Legionów i w sprawach taborów podlega Komendzie Legionów Polskich. Kapitan Passella był jak dotąd czynnym oficerem austriackiego pułku ułanów, tuż przed awansem na majora. Kapitan Pasella nadaje się wybornie na pozycję dowódczą w służbie amunicyjnej i taborach na wykonywanym stanowisku w Legionach. Jest bardzo pilny i aktywny, wyborny jako organizator. Mógłby być moim zdaniem najodpowiedniejszą osobą do postawienia na czele taborów Polskiej Siły Zbrojnej i samodzielnego pełnienia dalszej funkcji dowódcy. Pasella mówi dobrze po niemiecku, jest bardzo taktowny, także współpraca z nim opiera się na obustronnym zaufaniu i zrozumieniu, i nie może być lepsza.

Dalej, jako komendant dywizjonu odpowiedni mógłby być jeszcze kapitan Torma $^{34}$, dowódca polskich piekarni legionowych. Torma był wcześniej czynnym wachmistrzem armii austriackiej, jest bardzo energiczny i roztropny, ma także porządek w swojej kolumnie. Jego formacja społeczna jest wystarczająca, pozostałe zachowania sa swobodne i pozwalaja postrzegać go jako odpowiedniego na stanowisko dowódcy dywizjonu w trakcie trwającej wojny.

Perkowski ${ }^{35}$

32 Staffel.

${ }^{33}$ Karol Pasella (1876-1938) - w latach 1897-1909 żołnierz austriacki 45 pp z Sanoka, od 1 XI 1905 ppor. Następnie w 4 Pułku Dragonów (1909-1911) i 1 Pułku Ułanów (1911-1914). Od 1 V 1914 rtm. kaw., do marca 1915 r. dow. taborów 4 Dywizji Kawalerii. Przeniesiony do LP, od 1 IV 1916 r. szef Intendentury i kom. taborów. Następnie mjr w PKP, internowany po bitwie pod Rarańcza. Po 1918 r. na wielu stanowiskach w Ministerstwie Spraw Wojskowych (MSWojsk.) Od 30 IV 1927 r. w st. sp., płk tab. Zob. https://zolnierze-niepodleglosci. pl/\%C5\%BCo\%C5\%82nierz/213887/ (dostęp: 18 IV 2020).

${ }^{34}$ Stefan Torma (1881-1924) - w latach 1898-1901 żołnierz austriacki 8 pu, po 1910 członek i instruktor ZS, absolwent kursu ofic. Żołnierz i kom. komp. w 3 pp LP, od 20 X 1914 r. por. piech. Od czerwca 1915 r. w Intendenturze LP, oficer prowiantowy. 1 VII 1916 awansował na kpt. prow., kierownik piekarni polowych. Po kryzysie przysięgowym w PKP, z-ca kom. i kom. taborów. Aresztowany i internowany po Rarańczy. Po 1918 r. w WP w stopniu rtm. i kpt. rach. w WP, dow. taborów 1 DP Leg. w wojnie polsko-bolszewickiej. Zweryfikowany w 1921 r. w stopniu ppłk. tab. Zmarł w trakcie służby w X Dyonie Tab. w Przemyślu. Zob. https://zolnierze-niepodleglosci.pl/\%C5\%BCo\%C5\%82nierz/228642/ (dostęp: 18 IV 2020).

${ }^{35}$ Rudolf Perkowski - rotmistrz od 1 X 1913 r., poprzednio komendant Estaffelsabteilung w 92 Dywizji Piechoty. 
Do Inspekcji Wyszkolenia Polskiej Siły Zbrojnej w Warszawie.

Sprawozdanie do zarządzenia z 1.3.1917 Dz. nr 89 pers. dotycz. stanu wyszkolenia, nastrojach w pol. oddziałach.

$[\ldots]$

Spośród polskich oficerów większa część przejawia małe zainteresowanie praktyczną służbą. Prawdziwą rzetelność służbową można zaobserwować jedynie u nielicznych. Postawa i zachowanie przed frontem oddziałów stała się wprawdzie - jak powiedziano na wstępie - już znacząco lepsza, pozostawia jednak u większości, wedle niemieckich standardów, wiele do życzenia, komendy nadal sa przez większość wydawane tak cicho, że nie sa zrozumiałe dla wszystkich żołnierzy oddziału. Z tego powodu jako realizacja błędnych zapatrywań musi być postrzegane, że prawie wszyscy polscy oficerowie zajmują się w domu pilnym i regularnym studiowaniem, celem przyswajania teoretycznej wiedzy służbowej. Nie rozumieja jednak, że wiedzę teoretyczna należy ćwiczyć w praktyce. Wielu z nich sądzi, że sama wiedza teoretyczna wystarczy do osiagnięcia wyższych stanowisk dowódczych. Każdy podporucznik i choraży chce być co najmniej dowódcą kompanii. Należy jeszcze wspomnieć, że przechwalają się oni swymi osiagnięciami w polu. Prawie wszyscy oficerowie muszą być nadal kształceni w punktualności.

Do szkolenia rekrutów nadaje się faktycznie mniejszość oficerów, a także ci wymagają wsparcia przez oficerów niemieckich.

Ocena komendantów batalionów i kompanii.

Spośród komendantów kompanii żaden, z wyjątkiem może kapitana Kuli-Lisa ${ }^{36}$, o którym jeszcze będzie mowa, nie nadaje się do zajmowania wyższego stanowiska. Wedle niemieckich standardów sa oni, nawet przy złagodzonej ocenie, niezdolni wypełniać obowiązki komendantów kompanii. Panowie ci robią na mnie wrażenie interesujących i energicznych ludzi. Dobrych zdolności dowódczych nie ma żaden z nich. Wszystkim brakuje też niezbędnego u przełożonych ostrego spojrzenia, któremu nie może umknąć

${ }^{36}$ Leopold Lis-Kula (1896-1919). Zob. F. Demel, W. Lipiński, Pułkownik Leopold Lis-Kula, przedm. A. Piłsudska, Warszawa 1932; J. Kaden-Bandrowski, Leopold Lis-Kula Putkownik, Warszawa 1937; J. Magdoń, Leopold Lis-Kula, Kraków 2019; J.T. Nowak, Droga życiowa putkownika Lisa-Kuli, Przemyśl 1985; B. Zaniewski, Wspomnienie o Leopoldzie Lisie-Kuli żotnierzu legionowej legendy, Wrocław 1992. 
żaden błąd i żaden brak. Wobec praktycznej służby prawie wszyscy przejawiali tylko niewielkie lub całkowity brak zainteresowania. Muszę w tym miejscu wspomnieć, że ta ogólna obojętność oficerów, wedle mojej opinii, może być spowodowana $\mathrm{w}$ dużej części tym, że panowie zbyt wiele zajmuja się teoria, a tylko pozornie wielkimi praktycznymi zadaniami. Wielu spośród tych panów jest w skutek tego bardzo zarozumiałych i zachowuje siebie do wyższych celów. Ich wykorzystanie na niższych stanowiskach może dlatego nastręczać wyraźnych trudności.

Na komendanta batalionu, względnie pułku, mogą się wedle mojej osobistej opinii nadawać, jeśli nie przykładać do nich niemieckich kryteriów, tylko następujacy panowie:

1) Major Fabrycy ${ }^{37}$, komendant I batalionu.

Robi on ma mnie wrażenie obowiązkowego, spokojnego, roztropnego i rozumnego człowieka, który faktycznie stara się poszerzyć nie tylko swoja teoretyczna, lecz także praktyczną wiedzę służbową. Zasłużył sobie w oczach polskich towarzyszy, co można często usłyszeć, na opinię najzdolniejszego oficera pułku. Dowodził on już w zastępstwie przez 2 miesiace pułkiem w polu. Na wszelkie sugestie i życzenia niemieckiego doradcy, co powinno być szczególnie podkreślone, przystaje chętnie. Major Fabrycy ma bardzo sympatyczną osobowość. Względem niemieckich oficerów przejawiał zawsze przyjaźń i w każdym sensie życzliwość.

2) Kapitan Kukiel ${ }^{38}$, dowódca II batalionu, jest wprawdzie także bardziej teoretykiem niż praktykiem, przejawia się w nim jednak też dążenie, by przyswoić sobie jak najwięcej praktycznej wiedzy służbowej. Przyjmuje tė̇ z wdzięcznością każdą sugestię niemieckiego doradcy. Jest energiczny i zrozumiał też jak wzbudzać respekt u swych podkomendnych oraz forsować swoja wolę. Jest ponadto bardzo rozumnym, rozważnym i spokojnym człowiekiem. Jego zachowanie przed frontem [oddziałów] było stosunkowo dobre. Także on był względem niemieckich oficerów zawsze miły i uprzejmy.

Kukiel został przed około 5 tygodniami odkomenderowany do Warszawy jako uczestnik kursu, jak powiedziano, na oficera sztabu generalnego ${ }^{39}$.

${ }^{37}$ Kazimierz Fabrycy (1888-1958). Zob. https://zolnierze-niepodleglosci.pl/\%C5\%BCo\%C5\%82nierz/189738/ (dostęp: 18 IV 2020).

${ }^{38}$ Marian Kukiel (1885-1973). Zob. Historia - Wojsko - Polityka. Marian Kukiel (1885-1973) $i$ jego dzieto, red. T. Siewierski, Z. Zielonka, Warszawa 2019; Z. Jagodziński, Bibliografia prac i pism gen. Mariana Kukiela za lata 1904-1976, „Teki Historyczne” 1978/1980, t. XVII, s. 133-245; R. Stobiecki, Marian Kukiel (1886-1973). Historyk, który ,życie poświęcit nauce, a naukę Ojczyźnie”, w: idem, Historycy polscy wobec wyzwań XX wieku, Poznań 2014, s. 57-94; J. Zuziak, Generał Marian Kukiel (1885-1973). Żotnierz, historyk, polityk, Pruszków 1997.

${ }^{39}$ Kukiel ukończył kurs i jako jeden z trzech oficerów został uznany za zdatnego do służby w Sztabie Generalnym (SG). CAW WBH, KLiDPKP, I.120.1.295a, Rozkaz Komendy Legionów nr 280, Warszawa 22 III 1917 r., k. 170. 
3) Kapitan Wieczorkiewicz ${ }^{40}$ jest $w$ swym zachowaniu przed frontem [oddziałów] prawdziwie energiczny i zdecydowany. Posiada stosunkowo dobre doświadczenie dowódcze. Od stycznia 1915 jest kapitanem ${ }^{41}$. Tutaj jest dowódca III batalionu. W polu powinien on jeszcze dowodzić batalionem przez 2 miesiacce. Z usposobienia jest nieco skryty, może także być nawet zamknięty w sobie. Dlatego jest bardzo trudno przedstawić na jego temat właściwą ocenę. Z początku ignorował sugestie i życzenia niemieckiego doradcy niemal zupełnie. Od kilku tygodni zmienił swoją postawę w tym względzie.

4) Kapitan Kula-Lis jest jeszcze bardzo małoletnim człowiekiem. Nie ma jeszcze pełnych 21 lat. Jak słyszałem, za swoją odwage w obliczu wroga został on przedwcześnie mianowany kapitanem i otrzymał ponadto Krzyż Żelazny II kl. ${ }^{42}$ Kula-Lis robi na mnie wrażenie bardzo pilnego, ambitnego i zdolnego człowieka. Jego postawa przed frontem [oddziałów] jest prawdziwie energiczna i dobra. Ma on także dobre zdolności dowódcze.

Pomimo swego małoletniego wieku posiada żelazną wolę i potrafi ją także przeforsować. Doszedłem do wniosku, że ten młody oficer w dalszym praktycznym szkoleniu rokuje wielkie nadzieje. K. jest przyjacielskim, sympatycznym człowiekiem. Aktualnie zastępuje on odkomenderowanego kapitana Kukiela w kierowaniu II batalionem.

Uważam, że można zaproponować majora Fabrycego na komendanta pułku, a trzech wskazanych kapitanów na komendantów batalionów.

Najstarszy niemiecki oficer przy 1. Polskim Pułku Piechoty

Stensler ${ }^{43}$

Kapitan

\section{3}

Najstarszy niemiecki oficer

przy 1. Polskim Pułku Piechoty

Warszawa, 12 III 1917

Ocena komendanta pułku i komendantów batalionów

1) Major Fabrycy

2) Kapitan Kukiel

3) Kapitan Kula

4) Kapitan Wieczorkiewicz

\footnotetext{
${ }^{40}$ Wacław Scaevola-Wieczorkiewicz (1890-1969). Zob. J. Majka, Generat brygady Wacław Scaevola-Wieczorkiewicz 1890-1969. Krótka biografia wojskowa, Rzeszów 2018.

${ }^{41}$ Faktycznie od 5 III 1915 r.

${ }^{42}$ Był to austriacki Żelazny Krzyż Zasługi, przyznany 10 XII 1916 r.

${ }^{43}$ Oficer 33 pp Landwehry. Faktycznie najstarszym oficerem przy pułku był mjr Kilbach.
} 
wypełniali swoje obecne obowiązki z [nieczytelne] i dobrymi efektami, nie nadają się jednak w toku dalszego wystawiania polskich pułków do objęcia wyższych stanowisk.

Pułkownik Smygły[sic!]-Rydz ${ }^{44}$ podejmuje najlepsze starania celem wyszkolenia swojego korpusu oficerskiego, podoficerów i żołnierzy wedle wzorów niemieckich. Pozostaje jednak nadal nazbyt pod wpływem swych oficerów, którym nie odpowiada pruska dyscyplina i porządek a w skutek jego dobroduszności nie przenikają one dostatecznie energicznie.

Zatrzymałbym go przy późniejszym rozwijaniu polskich pułków do wykorzystania na jego aktualnym stanowisku.

Kilbach $^{45}$

Major

Kom. Wyszk. przy 2 pol. pp.

przy 1 Pol. pp.

Zambrowo [sic!], 6 III 1917

Sprawozdanie wg. Dz. nr 89 pers. z 1.3.1917.

$[\ldots]$

III. Postrzeganie obowiazków ze strony pol. ofic.

Odnośnie pojmowania obowiązków mamy do czynienia z wyraźnymi kontrastami. Podczas gdy niemieckie postrzeganie obowiązków wdarło się niektórym w duszę, są nadal inni, a ich liczba nie jest mała, którym ciężko przychodzi przyswojenie niemieckiego pojmowania obowiązków. Zdają się oni stać na stanowisku, że oficer ma więcej praw niż obowiązków. Punktualność w służbie, z początku pozostawiająca wiele do życzenia, aktualnie się poprawiła. Brakuje ostrych linii podziału między „służba” i „po służbie”, co przede wszystkim objawia się w stosunkach między przełożonymi i podwładnymi. $\mathrm{Na}$ wielu stanowiskach brakuje niezbędnego zainteresowania wykonywaniem zwykłych czynności służbowych. Studiowanie regulaminu służbowego musi

${ }^{44}$ Edward Śmigły-Rydz (1886-1941). Zob. R. Mirowicz, Edward Rydz-Śmigty. Działalność wojskowa i polityczna, Warszawa 1988; W.J. Wysocki, Marszałek Edward Śmigty-Rydz. Portret Naczelnego Wodza, Warszawa 2009; idem, Cień Zawiszy. Ostatnie lata Marszatka Edwarda Śmigłego-Rydza, Komorów 1991.

${ }^{45}$ Oficer $34 \mathrm{pp}$. 
być prowadzone rzetelniej. Zachowanie jako przełożonych i przed frontem [oddziałów] pozostawia prawie bez wyjątku wiele do życzenia. Język rozkazów jest wadliwy, pomimo częstych pouczeń poczyniono jak dotąd niewielkie postępy. Brakuje jeszcze zupełnie nie tylko niezbędnego zrozumienia dla znaczenia utrzymywania dyscypliny, lecz także z nielicznymi wyjątkami prawie całkowicie siły charakteru i siły woli niezbędnej dla zdolności utrzymywania zaprowadzonej dyscypliny. Jeśli pomimo to w oddziałach została zaprowadzona dyscyplina, to należy to przypisać wyłacznie i jedynie osobistemu wpływowi niemieckich doradców i wydaje się bardziej niż wątpliwe, czy polscy oficerowie po wycofaniu Komendy Wyszkolenia będą w stanie utrzymać i wzmacniać dyscyplinę.

\section{[...]}

Ocena komendantów komp. CKM, komendantów batalionów i komendanta pułku.

a. Komp. CKM, kom. komp. por. Siczek ${ }^{46}$ jest bardzo pilnym, skrupulatnym i wzorowo obowiązkowym oficerem, który wspierał doradcę we wszelkich relacjach. Jest bardzo chętny do nauki i jego największą ambicja w komp. jest zaprowadzenie tak dalece jak to możliwe niemieckiego drylu. Ma dobre spojrzenie na sprawy wojskowe, popełnione błędy natychmiast zauważa.

Por. Siczek nadaje sie na komendanta komp. CKM w rozwijanej armii.

Kom. I batalionu major Mezyński[sic!] ${ }^{47}$ przejawia tak małe zainteresowanie i dbałość o czynności służbowe batalionu, jak jest to niezbędne. W trakcie 6 tygodni pojawił się w służbie na ćwiczeniach przelotnie jedynie 2 razy, można go zastać tylko rzadko w koszarach, kuchni batalionowej, biurze batalionu. Rozkazy i zarządzenia dla kompanii wydaje tylko w bardzo rzadkich wypadkach, jedynie gdy jest to niezbędne i zwykle z opóźnieniem albo w tak niedokładnej formie, że dowódcy kompanii nie wiedzą czego dotyczą. Major M. nie rozumie ani swojej roli jako kom. baonu w pilnowaniu oficerów, jak też w karaniu z wymaganą surowością żołnierzy za przewinienie służbowe. Wedle mojej opinii jest w żadnym razie niezdolny do zajmowania stanowiska dowódcy baonu, a co dopiero wyższego stanowiska.

${ }^{46}$ Stanisław Siczek (1885-?) - działacz „Sokoła”, w 1914 r. żołnierz 2 pp LP. 5 XI 1914 chor. piech., od grudnia komp. ckm pułku. Awansowany 30 IV 1915 na ppor., 1 XI 1915 na por., a w październiku 1916 r. na kpt. piech. Od 1918 r. w WP, zweryfikowany jako ppłk uzbr. Do czasu przejścia w st. sp. w 1938 r. pracował na różnych stanowiskach w broniach technicznych i MSWojsk. Zob. https://zolnierze-niepodleglosci.pl/\%C5\%BCo\%C5\%82nierz/221200/ (dostęp: 18 IV 2020).

47 Włodzimierz Józef „Kościesza” Mężyński (1889-1918) - jednoroczny ochotnik w austriackim 4 pp. Członek ZS, od 1914 r. żołnierz 2 pp LP. We wrześniu 1914 mianowany chor., 27 I 1915 ppor., a 26 V 1915 por. piech. i kom. plut. Awansowany 1 XI 1915 na kpt., a 16 IV 1916 na mjr. piech. i kom. baonu 2 pp LP. Trzykrotnie p.o. dow. pułku. Po kryzysie przysięgowym w PKP, zmarł na atak serca. Zob. https://zolnierze-niepodleglosci. pl/\%C5\%BCo\%C5\%82nierz/208599/ (dostęp: 18 IV 2020). 
Dow. II bat. kpt. Smorawiński ${ }^{48}$ przejawia duże zainteresowanie służbą i wyszkoleniem, próbuje je prowadzić z rzetelnością i jak najlepiej. Wedle niemieckich standardów nie nadaje się na kom. baonu, ponieważ brakuje mu wiedzy, doświadczenia i energii.

Dow. III bat. kpt. Lukowski [sic! ${ }^{49}$ został odkomenderowany na kurs do Gen. Gub. ${ }^{50}$ Jest już od dłuższego czasu w pułku jako kom. baonu.

Spośród kpt./por., którzy są dowódcami kompanii, żaden nie nadaje się na kom. baonu w formowanej armii.

Ppłk Żymierski ${ }^{51}$ przejawia duże zainteresowanie wyszkoleniem i wychowaniem ofic., podofic. i żoł. w trakcie i po służbie, z zapałem usiłuje także wychować pułk wedle rad niemieckich doradców w duchu niemieckiego porządku i obowiązku, jest jednak zbyt mało energiczny. Brakuje mu wyraźnie wiedzy i spojrzenia w służbie wychowawczej i bojowej, tak by mógł samodzielnie i niezależnie kierować skutecznie regulaminowym szkoleniem rekrutów, kompanii, batalionów i pułku. Ponadto, przy najdrobniejszych inspekcjach celem potwierdzenia postępów wyszkolenia, uważa on niemal wszystko za właściwie wykonane, chociaż można by wskazać wiele błędów. Także w trakcie ćwiczeń terenowych przyjmuje z wyrozumiałością niezręczne zarządzenia kom. baonów i komp., pozwala toczyć się starciu tak jak się toczy, omawia niewiele, nie narzeka, wstrzymuje się od krytyki, jest ze wszystkiego bardzo zadowolony, chociażby uczaccy i instruujaccy krytycy mieli ostre uwagi już na placu ćwiczebnym. Jak ppłk. Ż. samodzielnie dowodzi, wydaje rozkazy bojowe i prowadzi starcia nie mogłem jak do tej pory stwierdzić.

Jego zasady taktyczne, których mimo wyjaśnień doradcy się trzyma, są przestarzałe.

Wedle niemieckich standardów ppłk Żymierski nie nadaje się na kom. pułku w nowo tworzonej armii, ponieważ brakuje mu wiedzy, doświadczenia i energii.

von Schmackowsky ${ }^{52}$ major i kierownik wyszkolenia

${ }^{48}$ Mieczysław Smorawiński (1893-1940). Zob. A. Kostrzewski, Smorawiński Mieczysław Makary (1893-1940), w: Polski Stownik Biograficzny (PSB), t. XXXIX, Warszawa-Kraków 1999-2000, s. 342-345; G. Mazur, Generat Mieczysław Smorawiński. Syn ziemi turkowskiej i kaliskiej, Turek 2012.

${ }^{49}$ Kazimierz Orlik-Łukoski (1890-1940). Zob. Z. Gnat-Wieteska, Generał brygady Kazimierz Orlik-Łukoski, Pruszków 2018; P. Stawecki, Stownik biograficzny generałów Wojska Polskiego 1918-1939, Warszawa 1994, s. 203-204.

${ }^{50}$ Kurs ukończył, został jednak uznany za niezdatnego do służby w sztabach i adiutanturze. Zob. przypis 39 .

${ }^{51}$ Michał Żymierski (do 1913 r. Łyżwiński; 1890-1989). Zob. J. Pałka, T. Pawłowski, Praca nad biografia Michała Żymierskiego prowadzona przez Wojskowy Instytut Historyczny $w$ latach siedemdziesiatych i osiemdziesiatych, „Dzieje Najnowsze” 2014, nr 1, s. 157-171; J. Pałka, J. Poksiński, Michat Żymierski 1890-1989, Warszawa 2015.

${ }^{52}$ Friedrich von Schmackowsky - mjr służby czynnej od 5 X 1916 r., poprzedni przydział III batalion 269 pp. 


\section{Sprawozdanie}

Zegrze, 7 III 1917

wg zarządzenia Inspekcji Wyszkolenia z 1.3.1917 nr 89 pers.

\section{$[\ldots]$}

Nie można porównać pojmowania obowiązku służbowego przez oficerów polskich do oficerów niemieckich. Tylko pojedynczy oficerowie zbliżają się do pożądanego postrzegania służby, które dominuje w niemieckim korpusie oficerskim. Poprzez długa, prawidłową i niezakłóconą pracę, może zostać osiagnięta zmiana $\mathrm{w}$ tym sensie.

Nieprzydatni oficerowie muszą być wykorzystywani do czasu wykształcenia użytecznego zastępstwa dla korpusu oficerskiego spośród młodszych oficerów. Ci muszą zostać wychowani na sumiennych oficerów w zgodzie z A. K. O. z 2 maja 1874 r. o Sądach Honorowych ${ }^{53}$.

Dobra wola jest ogólnie dostępna, jedna tak stare tradycje nie moga szybko wrosnać w krew i ciało zebranego w czasie wojny korpusu oficerskiego.

Gdy polskie pułki zostaną ukształtowane przez niemieckich oficerów z uwzględnieniem przedłożonego punktu widzenia, możemy otrzymać użyteczne oddziały, wspierające króla i Rzeszę oraz spełniające wszelkie wymagania bojowe.

Co do przedstawionych panów na dowódcę pułku nadają się:

1) Komendant batalionu Major Sajons [sic! ${ }^{54}$

Jest on jednym z najpilniejszych i świadomych obowiązków oficerem.

2) Major Taranabowicz [sic!! $]^{55}$

Jako komendant batalionu [w przyszłości] mógłby być jeszcze brany pod uwagę kapitan i komendant batalionu Szczepan ${ }^{56}$. Wedle uzdolnień i umie-

${ }^{53}$ Verordnung über die Ehrengerichte der Offiziere im Preußischen Heere vom 2. Mai 1874, Berlin 1874.

${ }^{54}$ Józef Zając (1891-1963). Zob. J. Majka, Generat Józef Zajac Legionista Lotnik Naukowiec, Rzeszów 2012; J. Zając, Dwie wojny, t. I-II, Londyn 1964-1967.

${ }^{55}$ Stanisław Tarabanowicz (1877-?) - absolwent austriackiej szkoły oficerskiej, od 18 VIII 1898 chor. piech. Następnie żołnierz 19 pp Landwehry, słuchacz szkoły SG (1906-1908). 1 XI 1912 mianowany kpt. Od 1914 w sztabie I Korpusu i dow. baonu 19 pp Landwehry. W maju 1916 przniesiony do LP, w sztabie II Brygady w randze mjr SG piech. Następnie kom. baonu rekruckiego 3 pp LP. W sierpniu 1917 r. powrócił do armii austriackiej. Po 1918 r. w WP, w 1920 płk SG piech. Służył m.in. w 23 i 27 DP. 30 IX 1927 przeszedł w st. sp. Zob. https://zolnierze-niepodleglosci.pl/\%C5\%BCo\%C5\%82nierz/227869/ (dostęp: 18 IV 2020).

56 Józef Szczepan (1885-1936) - od 1912 instruktor Drużyn Polowych „Sokoła”. Od 1914 w LP, służył w 3 pp, 28 IX 1914 ppor., 25 X 1914 por. piech. W czerwcu 1915 r. kom. komp. w randze kpt., służył też w oddziale sztabowym 3 pp. W latach 1916-1916 dwukrotnie p.o. kom. pułku. Pozostał w PKP, potem w I Korpusie Polskim. Od 15 XI 1918 r. 
jętności nadaje się on do tego. Ma silną i zdecydowaną postawę przed frontem i w wydawaniu rozkazów. Przez niedostateczna pilność i podejście do szkolenia nie jest wzorem dla korpusu oficerskiego. To neguje równocześnie możliwość wykorzystania go na korzyść batalionu.

\author{
von Enckevort ${ }^{57}$ \\ major i najstarszy oficer niemiecki \\ Komendy Wyszkolenia \\ przy 3 polskim Pułku Piechoty
}

\title{
6
}

Personalne nr 3

Zegrze, 13.3.17

\section{Dodatkowy meldunek}

do dz. nr 89 pers. z 1.3.17

1) Podpułkownik Galiza[sic! ${ }^{58}$ jest szlachetny z usposobienia. Jego maniery i zachowanie pozostawiaja jednak wiele do życzenia. Jest jednak bardzo chłonny i podążą za radami. Brakuje mu jednakże energii by forsować swoja wole w pełni i całkowicie w korpusie oficerskim, musi także bardziej dbać o praktyczną służbę. Ponieważ jednak z biegiem czasu można zaobserwować poprawę, myślę, że przy dalszej nauce będzie mógł później pełnić swoja funkcję jako komendant pułku.

2) Pułkownika Hallera ${ }^{59}$ uważam za nadającego się do dowodzenia brygadą.

von Enckevort

major i najstarszy oficer niemiecki Komendy Wyszkolenia przy 3 pol. pp

w WP, mjr piech. Między innymi dow. 3 pp Leg (1919-1920), następnie 47 i 48 pp w stopniu ppłk. piech. Przeniesiony do rezerwy 6 V 1922 r. Zob. https://zolnierze-niepodleglosci. pl/\%C5\%BCo\%C5\%82nierz/226213/ (dostęp: 18 IV 2020).

${ }_{57}$ Julius von Enckevort - mjr od 1 X 1912 r. Poprzedni przydział 156 pp.

58 Andrzej Galica (1873-1945). Zob. A.A. Kozłowska, Góral generałem - Andrzej Galica. Biografia żotnierza, polityka i literata, Łódź 2013.

${ }_{59}$ Józef Haller de Hallenburg (1873-1960). Zob. S. Aksamitek, Generat Józef Haller. Zarys biografii politycznej, Katowice 1989; E. Ligocki, O Józefie Hallerze. Życie i czyny na tle wspótczesności dziejowej, Warszawa 1923; I. Modelski, Józef Haller w walce o Polskę niepodlegta $i$ zjednoczona, Toruń 1936; M. Orłowski, Generat Józef Haller 1873-1960, Kraków 2007. 
Komenda Wyszkolenia

Zegrze, 11 III 1917

przy 4 Pułku polskich Legionów

Dziennik poufny 2

Sprawozdanie

wg zarządzenia Inspekcji Wyszkolenia nr 89 pers. z 1.3.1917

$[\ldots]$

Wśród oficerów stopniowo umacnia się akceptacja niemieckiego charakteru, niemieckiego porządku i dyscypliny, chociaż w tym niejako wymieszanym korpusie oficerskim, który składa się z reprezentantów różnych terenów, różnych profesji i klas społecznych, część nie chce się z tego cieszyć; niektórzy hołduja w służbie i poza służbą bardziej austriackim manierom i zwyczajom, niektórzy sa politykami i dbają o tę działalność zamiast dostrzegać główne zadanie w wypełnianiu swych obowiązków oficerskich; większość wykorzystuje w nieakceptowalnie niskim sensie czas wolny do samodoskonalenia i uzupełnienia luk w wiedzy wojskowej, tak, że byłoby także właściwsze szkolić rekrutów pod kierunkiem niemieckich doradców; niemieckie postrzeganie obowiązku i dokładność, także w pozornie nieważnych sprawach, muszą się stać jeszcze bardziej dobrem wspólnym.

[...]

Spośród dotychczasowych komendantów batalionów I. bat. kpt. Zarzycki ${ }^{60}$, II. bat. kpt. Sikorski ${ }^{61}$, III. bat. kpt. Szerauc ${ }^{62}$, bat. rekrucki kpt. Więckowski ${ }^{63}$,

${ }^{60}$ Ferdynand Zarzycki (1888-1958). Zob. L. Dall, Gen. bryg. Ferdynand Zarzycki (1888-1958). Doktor filozofi, skaut, nauczyciel, minister i senator, „Skaut. Harcerskie Pismo Historyczne” 2007, nr 4 (12) s. 2-5; P. Stawecki, Stownik biograficzny..., s. 363-365.

${ }^{61}$ Franciszek Sikorski (1889-1940). Zob. H. Korczyk, Sikorski Franciszek Józef (1889-1940), PSB, t. XXXVII, Warszawa-Kraków 1996-1997, s. 434-435; A. Leinwand, Generał Franciszek Sikorski: Dowódca Grupy Obrony Lwowa w 1939 roku, „Niepodległość i Pamięć” 1995, nr 2/3, s. 19-41; Sz. Nowak, Franciszek Sikorski, Kraków 2020.

62 Edward Szerauc (1859-1937) - od 1874 w austriackiej Szkole Kadetów w Łobzowie, wydalony za udział w spisku antypaństwowym. Następnie leśnik, od 1894 działacz „Sokoła”. Od 1914 r. w LP, żołnierz 2 pp. Od 29 IX 1914 r. chor. piech., od 20 X 1914 r. por. piechoty, dowódca komp. i baonu w 2 pp. Prowadził werbunek wśród Hucułów. Od maja 1915 r. organizator i dowódca baonu w 4 pp LP. Uczestnik walk na Lubelszczyźnie i Wołyniu. Od 19 VIII 1916 r. hospitalizowany. Pod kryzysie przysięgowym dow. 4 pp LP w stopniu kpt. piech., następnie w PKP. Internowany po Rarańczy. Przyjęty do WP 3 XI 1918 r., organizator odtwarzania 4 pp Leg. 12 IX 1918 r. mianowany mjr. W latach 1919-1920 m.in. kom. twierdzy Osowiec i oficer ds. specjalnych poruczeń 2 Armii WP. 26 I 1922 przeniesiony do rezerwy w stopniu ppłk. piech. Zob. https://zolnierze-niepodleglosci. pl/\%C5\%BCo\%C5\%82nierz/226570/ (dostęp: 18 IV 2020).

${ }^{63}$ Mieczysław Więckowski (1895-1926) - student medycyny, od 1910 r. członek „Zarzewia”, od 1911 w Polskich Drużynach Strzeleckich (PDS), w kolejnym roku w Drużynach Polowych 
tylko pierwszy z wspomnianych mógłby, gdyby było to konieczne, być brany pod uwagę jako komendant pułku. Jest on młodym, ambitnym, obowiązkowym oficerem, prawdziwie stara się by wychować i wyszkolić swój oddział wedle niemieckich wzorów. Solidny, bardzo ambitny i skrupulatny jest dowódca baonu rekruckiego kapitan Więckowski; jest on jednak nadal zbyt młody na stanowisko komendanta pułku.

Spośród komendantów kompanii na dowódcę batalionu mógłby być brany pod uwage kapitan Smolarski ${ }^{64}$, czasowo odkomenderowany na kurs szkoleniowy do Warszawy ${ }^{65}$.

Thiel $^{66}$

major w 4. Pułku polskich Legionów

„Sokoła”. Od sierpnia 1914 r. w LP, kom. plutonu w 2 pp. 29 IX 1914 chor., a 11 XI 1914 ppor. piech. Następnie adiutant baonu i kom. komp. Od stycznia 1915 r. hospitalizowany. Od lipca 1915 r. w 4 pp LP, kom. kompanii. Od 20 VIII 1915 r. por., a od 1 VII 1916 kpt. piech. Od grudnia 1916 r. do stycznia 1917 r. kom. baonu rekruckiego, potem kom. baonu w Obozie Wyszkolenia Piechoty nr II. Po kryzysie przysięgowym zwolniony z wojska i uznany za czasowo niezdolnego do służby. Członek POW, ponownie student medycyny. Uczestniczył w rozbrajaniu wojsk austriackich w Krakowie, od 15 XI 1918 r. mjr piech. w WP. Uczestnik odsieczy Przemyśla i Lwowa. Następnie oficer operacyjny Dowództwa Okręgu Generalnego (DOGen.) Kraków. Słuchacz Kursu Szkoły SG w 1920 r., który ukończył po wojnie polsko-bolszewickiej. W 1921 r. ppłk w 4 pp Leg., od września tego roku szef sztabu DOK II Lublin. Od 15 VIII 1924 r. płk SG piech. Zwolennik zamachu majowego, popełnił samobójstwo. Zob. https://zolnierze-niepodleglosci.pl/\%C5\%BCo\%C5\%82nierz/231211/ (dostęp: 18 IV 2020).

${ }^{64}$ Władysław Smolarski (1895-1975) - student Studium Rolniczego Uniwersytetu Jagiellońskiego (UJ). Od 1910 r. działał w skautingu, członek „Sokoła”. Od sierpnia 1914 r. w LP, słuchacz I kurs Szkoły Podchorążych. LP, 5 XI tego roku mianowany ppor. piech. Kom. plut. i komp. w 2 pp LP. Od 2 VII 1915 por. piech., przeniesiony na dow. komp. w 4 pp LP. Hospitalizowany, od września tego roku kom. baonu i komp. 1 VII 1916 kpt. piech. i kom. baonu 4 pp. Po kryzysie przysięgowym w PKP, internowany po Rarańczy. W maju 1918 r. wcielony do armii austriackiej, walczył na froncie włoskim. Od 1 XI 1918 r. w WP, kom. baonu 4 pp Leg., następnie referent w PKW w Krakowie. Szef sztabu odsieczy Lwowa, awansowany na mjr. piech. Uczestnik wojny polsko-bolszewickiej na stanowiskach sztabowych, oficer sztabu DOGen. Łódź (1919-1921). Następnie na kursie doszkalającym oficerów SG, szef sztabu 2 DP Leg. Od 21 X 1922 r. w MSWojsk. W 1923 absolwent na Wyższej Szkoły Wojennej (WSWoj.), od 12 X tego roku w DOK V w Krakowie. 17 I - 14 XII 1925 w stanie nieczynnym, następnie w SG. 12 VI 1926 szef sztabu 23 DP, od 1 I 1927 ppłk SG piech. Następnie służba na stanowiskach liniowych i sztabowych w 81, 18 i 86 pp oraz DOK w Łodzi. 1 I 1934 r. płk dypl. piech., od czerwca szef Oddziału IV Sztabu Głównego. Uczestnik kampanii polskiej jako dow. piech. 17 DP, w niewoli niemieckiej. Zmarł w Krakowie. Zob. https://zolnierze-niepodleglosci.pl/\%C5\%BCo\%C5\%82nierz/222775/ (dostęp: 18 IV 2020).

${ }^{65}$ Kurs ukończył, zostając uznany za zdatnego do służby w adiutanturze. Zob. przypis 39.

${ }^{66}$ Richard Thiel - mjr od 22 III 1914 r., ostatni przydział 52 pp. 
Komenda Wyszkolenia

Zegrze, 13.3.1917

przy 4 Pułku polskich Legionów

Dziennik nr 10 pers.

O pułkowniku Roji67.

\author{
Sprawozdanie \\ wg zarz. [brak numeru]
}

Pułkownik Roja jawi się jako zupełnie odpowiedni na stanowisko komendanta pułku; jeśli wciąż brakuje mu w porównaniu do niemieckich komendantów pułków niezbędnych cech, to jednak zalicza się do tych, którzy ze względu na swoją karierę wojskową dysponuja własną wiedzą i doświadczeniami. Po 8-letnim czasie czynnej służby wojskowej w armii austriackiej ${ }^{68}$, wziął jako podporucznik dymisję, stawiając się na początku wojny do dyspozycji Legionów i dowodził tutaj batalionem i pułkiem, wedle ocen swych towarzyszy powinien on przy tym posiadać odwagę, zdolność podejmowania decyzji i zręczność.

Jego wojskowe predyspozycje jawią się jako dobre, najmniejsze drobiazgi próbuje załatwiać samodzielnie, przykłada także wagę do wyszkolenia swojego korpusu oficerskiego i dbałości o siły żołnierzy.

Jest serdecznym towarzyszem, życzliwie sprawiedliwym przełożonym, zwolennikiem niemieckiej pilności, niemieckiego porządku i dokładności.

Jak większość oficerów Legionów zajmuje się on pilnie z polityka, jego idealny obraz przyszłości leży w nowej Wielkiej Polsce od morza do morza, w oparciu o silne Niemcy.

Wyszkolenie polskiej armii wedle niemieckiego wzoru może u niego znaleźć tylko wsparcie i pomoc.

Thiel major

${ }^{67}$ Bolesław Roja (1876-1940). Zob. H. Korczyk, Roja Bolestaw Jerzy (1876-1940), PSB, t. XXXI, Wrocław 1988-1989, s. 508-511; A.A. Kozłowska, Bolesław Roja. Legionowym szlakiem dowódcy czwartaków, „Zeszyty Wiejskie” 2018, z. 24, s. 69-91; P. Stawecki, Stownik biograficzny..., s. 278-279.

${ }^{68}$ Roja był absolwentem Szkoły Kadetów w Wiedniu (1895-1898), służył w armii austriackiej do 1905 r., gdy został przeniesiony do rezerwy z powodów zdrowotnych. 
Niemiecki Kom. Wyszkolen[ia] w 5. pol. Pułk. Piech.

24. Per.

\section{Sprawozdanie}

wg zarz. Inspekcji nr 89 pers. z 1.3.1917

\section{Stan wyszkolenia}

[...]

b. Taktyka i służba polowa

Komendantom batalionów są dostatecznie znane najważniejsze formy i zasady, sa także dość dobrze wyszkoleni pod względem taktycznym. Większość podoficerów i żołnierzy wykazuje samodzielność w działaniu, zręczność w wykorzystaniu terenu i poruszeniach, jak też przedsiębiorczość, jednakże wciąż wiele do życzenia pozostawiają prowadzenie walki ogniowej oraz środki wykorzystania broni własnej oraz niwelowania oddziaływania broni przeciwnika. Ponieważ polskim regulaminom brakuje przepisów strzeleckich, przepisów służby polowej i części dotyczącej ćwiczeń, czyni to sprawę szczególnie ważna. Polscy młodsi dowódcy, tzn. oficerowie, przeprowadzaja tylko to, co rozkaże komendant pułku i co zostanie zaaprobowane. Część z nich, która wywodzi się ze szkoły austriackiej, opiera się nadal na tych przepisach, jako jeszcze niezniesionych.

Pol. komendant pułku studiuje niemieckie regulaminy z wielkim zainteresowaniem i tłumaczy każdą książkę, którą mu daję, zleca też tłumaczenia dowódcom batalionów II i III. Jest on jednak nazbyt teoretykiem i brakuje mu praktyki. Rozumie tylko to, co ma przedstawione czarno na białym, identycznie, tylko w jeszcze większym zakresie, działaja jego podkomendni. Poza zarządzaniem grupa szkoleniową niemieckich podoficerów, która działa bardzo dobrze, przygotowuję dowódcy pułku w szczegółach pisemnie każde ćwiczenie i każdą inspekcję. Stosuje się on do powyższych i podąża za moimi radami. $[\ldots]$

\section{Nastroje w oddziałach}

Podoficerowie i żołnierze sa chętni i zręczni. Jeśli stan ich wyszkolenia nie wzrasta, to leży to [wina] głównie po stronie oficerów.

$\mathrm{Ci}$ sa po prostu nadal w większej części niedostatecznie gruntownie wyszkoleni, nie posiadaja niezbędnej wiary w siebie i wymaganego zdecydowania. Brakuje im zbyt często zmysłu i spojrzenia na dyscyplinę i porządek, instruują żołnierzy niedostatecznie, poprzestają na naukach i napomnieniach, nie udzielają nagan i kar tam gdzie sa potrzebne. 


\section{$[\ldots]$}

Nastroje względem niemieckich doradców są bardzo różne. Część oficerów chce się czegoś nauczyć i stara się współpracować z Niemcami, część podąża za ich radami tylko mimowolnie.

Niektórzy, choć przejmuja to co użyteczne, nastawiaja podkomendnych ogólnie przeciw Niemcom. Polscy oficerowie prawie bez wyjątków postrzegaja niemieckich doradców jako zło konieczne, przez które czują się kompromitowani wobec swych podkomendnych i rodaków. Mają wobec Niemców więcej szacunku, ale mniej sympatii niż do Austriaków, w zasadzie nienawidza Niemców tak samo jak Rosjan.

3. Pojmowanie obowiazków przez oficerów.

Komendanci batalionów i starsi kapitanowie starają się wypełniać swoje obowiązki. Spośród młodszych oficerów jedynie nieliczni przejawiają minimalne zainteresowanie teraźniejszą „służbą pokojową"69. Bardzo ogólnie nie należą do ich pojmowania obowiąku wysokie wymagania stawiane im i podwładnym co do energicznego wypełniania i stałego czuwania nad aspektami służby wewnętrznej i zewnętrznej oraz tożsamego poczucia obowiązku w sprawach małych, jak w wielkich. Oficerowie z lubościa przebywają w czasie służby w biurze kompanii i pozostawiaja podoficerów i żołnierzy samych sobie. W trakcie służby stoją najczęściej wokół swojego komendanta kompanii, spędzają czas gawędząc z nim, pozostawiając szkolenie podwładnym. Oczywiście także tutaj występuja pojedyncze wyjątki i wszystko może zostać stopniowo poprawione. Stosunki z podwładnymi nadal nie prezentują się właściwe, szczególnie brakuje dobrego przykładu. Przy wykroczeniach zadowalają się chętnie w wypadku swoim i podwładnych niedostatecznymi przeprosinami.

[...]

4. Zdolność szkolenia rekrutów.

Przy dostępnej realizacji, polscy oficerowie i podoficerowie nie sa zdolni do samodzielnego szkolenia rekrutów. Potrzebują do tego nie tylko niemieckich doradców, ale też niemieckiego kierownictwa.

Warsitz $^{70}$

Major i najstarszy niemiecki oficer wyszkoleniowy

\footnotetext{
${ }^{69}$ Friedensdienst.

${ }^{70}$ Klemens Warsitz - mjr od 25 XI 1916 r.
} 
Niemiecki Kom. Wyszk. w

Ostrów, 6.3.17

5. pol. Pułk. Piech.

24. Per.

\section{Ocena}

\section{Komendant pułku, major Burchardt-Bukacki [sic!] ${ }^{71}$}

Major B. jest jeszcze bardzo młody. Jego usposobienie jest bardzo zmienne. Czasem wykazuje inicjatywę, uprzejmość i zaufanie, wypowiada się, powierza mi swoje troski w prowadzeniu pułku, wychowaniu korpusu oficerskiego, $\mathrm{w}$ trudnej barierze między jego poglądami politycznymi a zapatrywaniami, które musiał przyjąć, powierza mi w zaufaniu, jak musi karcąco interweniować względem niezdyscyplinowana swych podwładnych i braku zainteresowania części oficerów; innym razem jest on przeciwnie niemal całkiem wycofany, obojętny, zupełnie nieufny, przyjmuje moje rady niestarannie, wykazując względem nich bierny opór. Muszę jednak powiedzieć, że szczególnie w ostatnim czasie nasze stosunki pozostawały naprawdę dobre. Aktualnie odbiera on pisemne propozycje i nauki chętniej i z zainteresowaniem, częściej szuka moich rad. W tym tygodniu chcemy, wedle jego prośby, razem przejść do opracowania regulacji dotyczacych służby wewnętrznej, stosunku do przełożonych i porządku dyscyplinarno-karnego jak też regulaminu skarg, które chce on przedłożyć jako propozycję, którą podda pod osąd Komendy Legionów.

Major B. jest niezwykle pracowity, czyta i tłumaczy wszystkie przepisy, zajmuje się wszystkimi gałęziami służby wojskowej, interesuję się gorąco wojna, jest żołnierzem z pasji, dobrym jeźdźcem, mówi z zapałem o pierwszym okresie wojny, gdy sam ze swym małym detaszowanym oddziałem został skierowany na granicę austriacka. To tłumaczy też jego zamiłowanie do małej wojny, której podstawom chce podporządkować wszystkie swoje ćwiczenia.

Uważam go za człowieka istotnego, który z niezbędnym doświadczeniem i szerszymi perspektywami życiowymi, z pewnością stanie się porządnym oficerem. Na razie nie jest jeszcze dostatecznie ukształtowany. Wiele niepojętych spraw daruje, podśmiewając się, gdy innym razem zarządza niepotrzebnie ciężkie kary aresztu dla swoich oficerów, tam gdzie bardziej na miejscu byłoby pouczenie.

Ostatecznie jest najzdolniejszy. Zachowuje dystans między sobą i podkomendnymi, nigdy nie bierze udziału w grach [karcianych], stara się nauczać i kształcić oficerów w naukach wojskowych. Jest od rana do wieczora na służbie, kontroluje wszystko na ile może. Mówi po niemiecku niemal płynnie.

Uważam go za odpowiedniego by dowodzić polskim pułkiem.

${ }^{71}$ Stanisław Burkhardt-Bukacki (1890-1942). Zob. P. Stawecki, Stownik biograficzny..., s. $88-89$. 


\section{Major w sztabie Trojanowski ${ }^{72}$}

Wiedza służbowa majora T. wymyka się zupełnie mojej ocenie. Widziałem go jak do tej pory tylko raz na służbie. Trzyma się z daleka od wszelkich narad, inspekcji, przeglądów, ćwiczeń pułkowych i batalionowych. Na początku bywał często na polowaniach. Gra pasjami [w karty]. Wedle mojej wiedzy nie dosiadł jeszcze konia. W szkole powinien uczyć historii wojen, ale żadnego innego przedmiotu. Z Niemcami rozmawia uprzejmie, jednak bardzo formalnie, utrudnia mu to bardzo słaba znajomość języka niemieckiego.

Nie mogę przedstawić oceny jego zdolności i wiedzy, ponieważ je zataił. Nie sądzę jednak by można było mu powierzyć pułk do szkolenia i kierowania.

3. Kapitan Karasiewicz-Tokaszewski [sic!]

K. jest austriackim oficerem rezerwy ${ }^{74} \mathrm{i}$ bazuje na wcześniejszych naukach. Ma jednak niewatpliwie najlepsze ze wszystkich rozeznanie w sprawach militarnych. W towarzystwie i w służbie jest równie swobodny, dba o dyscyplinę i porządek, rozumie swoją służbę, robi w związku z tym zbyt wiele, nie zostawiając swym dowódcom kompanii żadnej samodzielności.

Poza służbą bardzo solidny i wycofany, do tego uprzejmy. Podążał zawsze za radami swojego doradcy kapitana Lindiga ${ }^{75}$, którego uważał za starszego i bardziej doświadczonego oficera, jednak zawsze z określonymi zastrzeżeniami i samodzielnością. Niestety brakuje dla niego teraz starszego, energicznego doradcy.

Kapitan T. jest w każdym wypadku jednym z najzdolniejszych ze wszystkich komendantów batalionów i dorasta do swojego stanowiska. Mówi płynnie po niemiecku. Nieszczesśliwie był on długo chory na zapalenie płuc, tak, że musiał pozostać poza służba.

4. Kapitan Olszyna-Wilczyńskii ${ }^{76}$, komendant III batalionu

W. jest skrupulatnym, energicznym, uzdolnionym i dobrze wyszkolonym oficerem. Mówi właściwie dobrze po niemiecku, jest bliski płynności. Tłumaczy wszystkie dostępne przepisy i książki, próbuje też wyciagnąć z nich jak najwięcej nauk. Stosunki między nim i jego doradca, kapitanem Sanderem ${ }^{77}$, są właściwie dobre. Jest nadzwyczajnie solidny, nie gra [w karty] i daje dobry przykład w każdej sytuacji.

Jest zdatny do bycia dobrym kom. baonu w pol. armii.

${ }^{72}$ Mieczysław Trojanowski (1881-1945). Zob. https://zolnierze-niepodleglosci.pl/\%C5\%BCo\%C5\%82nierz/228834/ (dostęp: 18 IV 2020).

${ }^{73}$ Michał Tokarzewski (Tokarzewski-Karasiewicz, od 1927 Tokarzewski-Karaszewicz; 1892-1964). Zob. D. Bargiełowski, Po trzykroć pierwszy. Michat Tokarzewski-Karaszewicz. Generał broni, teozof, wolnomularz, kapłan Kościoła liberalnokatolickiego, t. I-III, Warszawa 2000-2002.

${ }^{74}$ Faktycznie był podoficerem, służył w 4 i 80 pp.

${ }^{75}$ Max Lindig - kapitan od 19 III 1913 r.

76 Józef Olszyna-Wilczyński (1890-1939). Zob. W. Jaskulski, Generat brygady Józef Konstanty Olszyna-Wilczyński (1890-1939), Włocławek 2013; A.E. Jędrzejewska, Bez prawa do chwały. Generał brygady Józef Olszyna-Wilczyński (1890-1939). Biografia, Łódź 2018.

${ }^{77}$ Hermann Sander - kapitan od 27 I 1906 r., II/11 pp. 


\section{Kapitan Narbutt-Łuczyński ${ }^{78}$}

N. jest Polakiem ${ }^{79}$ z okolic Warszawy. Dobra prezencja, świetny jeździec; potrafi być bardzo energiczny i dokładny względem swych podwładnych. Jego osobowość jest jeszcze subtelniejsza niż większości jego kolegów i trzyma się on zasadniczo na uboczu. Jest solidny i nie uznaje siły. Względem niemieckich oficerów był początkowo nieśmiały i nieprzystępny, co tłumaczy jego niemal całkowita nieznajomość języka niemieckiego. W ostatnim czasie stał się bardziej ufny. Niestety aktualnie brakuje także dla niego starszego, dobrze mówiącego po polsku i do tego uprzejmego doradcy.

Wprawdzie kpt. Narbutt także służbowo nie stoi na tym samym poziomie co jego obaj koledzy, uważam, że nadaje się na komendanta baonu w polskiej armii.

Warsitz Major

\section{1}

Niemiecki Kom. Wyszkolenia

przy 6. pol. Pułk. Piech.

Dot.: Stanu wyszkolenia i sprawozdania o służbie wg zarzadzenia Inspekcji nr 89 pers. z 1.3.1917.

Dz. 8 pers.

\section{Sprawozdanie}

\section{$[\ldots]$}

Postrzeganie przez oficerów obowiazków służbowych. Z niewielkimi wyjątkami wśród oficerów panuje bardzo swobodne podejście do służby. Wykroczenia i zaniedbania sa na porządku dziennym. Pojedynczy oficerowie zasadniczo wcale nie przychodzą na służbę. Komendant pułku nie robi nic by ukarać te zajścia.

$[\ldots]$

Stümpf $f^{80}$

Kapitan i najstarszy ranga oficer Przy niemieckiej Kom. Wyszkolenia 6. Pol. Pułku piechoty

\footnotetext{
${ }^{78}$ Aleksander Narbutt-Łuczyński (1890-1977). Zob. A. Narbutt-Łuczyński, U kresu wędrówki. Wspomnienia, Londyn 1966; P. Stawecki, Stownik biograficzny..., s. 202-203.

79 National-Pole - określenie używane przez Niemców w stosunku do Polaków z Kongresówki.

${ }^{80}$ Maximilian Stümpf - kapitan od 1 X 1913 r., 37 pp, 10 Landwehrbat.
} 


\section{Załacznik - Ocena komendantów}

\section{Załacznik do sprawozdania}

Ocena komendantów w 6. pol. p. piech.

\section{Komendant pułku}

Podpułkownik Norwid-Neugebauer ${ }^{81}$ jest wedle wypowiedzi swych własnych oficerów cywilem. Przejawia mało zrozumienia dla spraw wojskowych i nawet najmniejszego zainteresowania dla służby i przeszkolenia oddziałów wedle niemieckich wzorów. Podczas wizyty Pana Inspektora pojawił sie pierwszy raz na ćwiczeniach ${ }^{82}$. Nie zleca zasadniczo żadnych wykładów niemieckim oficerom.

Podąża bardzo opornie za sugestiami doradców, do realizacji przedłożonych zarządzeń w służbie wewnętrznej odnosi się całkowicie nieprzychylnie.

Wedle wypowiedzi jednego ze starszych oficerów pułku nie wykazuje żadnej aktywności względem oficerów i żołnierzy, chociaż wskutek częstych nieprzyjemnych i niesłusznych kar budzi strach. Z drugiej strony pozostawia korpusowi oficerskiemu dużo swobody, a ten robi z niej nieodpowiedni użytek. Swobodny stosunek do służby w korpusie oficerskim należy przypisać jemu samemu, ponieważ świeci złym przykładem.

W swych zachowaniu formalnym i pozasłużbowych nie daje korpusowi oficerskiemu dobrego przykładu. Wychowanie korpusu oficerskiego jest mu nieznane.

Uważam podpułkownika Norwida-Neugebauera za niezdolnego do zajmowania stanowiska komendanta pułku w przebudowywanym wojsku.

\section{Kom. I Bat.}

Kapitan Sagurski [sic!] ${ }^{83}$ jest eleganckim, inteligentnym, energicznym i bardzo pracowitym oficerem, który wykazuje prawdziwy wysiłek, by przeszkolić polskie oddziały wedle niemieckich wzorów.

Jako były oficer austriackiego Sztabu Generalnego posiada on zrozumienie spraw wojskowych i wiedzę, w których przewyższa oficerów pułku.

${ }^{81}$ Mieczysław Norwid-Neugebauer (1884-1954). Zob. M. Walak, Generat Mieczystaw Norwid-Neugebauer (1884-1954): szkic do biografii, „Niepodległość” 2013, t. LXII, s. 259-270.

${ }^{82}$ Barth wizytował 6 pp tuż przed powstaniem raportu. CAW WBH, KLPiDPKP, 120.1.68, Telegram z 4 III 1917 r., k. 5.

83 Włodzimierz Ostoja-Zagórski (1882-1927?) - ukończył austriacką Akademię Sztabu Generalnego i miał rangę kpt. tej formacji. 1 X 1916 r. awansował na mjr. J. Gaul, $Z$ działalności kapitana Włodzimierza Zagórskiego w latach 1914-1918, „Przegląd Historyczny” 1997, nr 1, s. 135-143; P. Kowalski, Generał brygady Włodzimierz Ostoja-Zagórski (1882-1927)biografia, Torun 2007; G. Kulka, Sprawy honorowe gen. Włodzimierza Ostoi-Zagórskiego w latach 1923-1928, „Dzieje Najnowsze” 2016, nr 3, s. 107-127. 
Cieszy się poważaniem w pułku i ma wpływ na oficerów, także na komendanta pułku. Szuka porad niemieckich oficerów i wspiera ich w każdym sensie.

Jest człowiekiem z charakterem i kompetentnym do wychowania korpusu oficerskiego.

Uważam kapitana Sagurskiego [sic!] za szczególnie predystynowanego na komendanta pułku w przebudowywanym wojsku.

\section{Kom. II Bat.}

Kapitan Tereltzki [sic! ${ }^{84}$ jest byłym czynnym oficerem austriackim. Jest energiczny i pracowity, ale przykro stwierdzić, że nie jest on przyjacielem Niemców i przeszkolenia wedle niemieckich wzorców.

Jego batalion jest $\mathrm{w}$ dobrym porządku.

Uważam kapitana Terletzkiego [sic!] za zdatnego na komendanta batalionu w przebudowywanym wojsku.

\section{Kom. III Bat.}

Kapitan Jakubowski ${ }^{85}$ dowodzi batalionem od ok. 10 dni. Jego praktyczna wiedza jest niewielka, ponieważ jak do tej pory sprawował tylko nadzór nad szkoła pułkowa. Jest jednak oficerem przepełnionym prawdziwymi staraniami, energicznym, pilnym w służbie, o dobrej formie. Wspiera doradców w każdym sensie i chce się od nich uczyć.

Prosiłem o to, by także po powrocie swego poprzednika dowodził batalionem.

Uważam kapitana Jakubowskiego za zdatnego na komendanta batalionu w przebudowywanym wojsku.

5. Kapitan Głowinski [sic! ${ }^{86}$ dowodził batalionem przed kapitanem Jakubowskim. Nie ma dobrego oglądu spraw wojskowych. Utrzymywał swój

${ }^{84}$ Edward Terlecki (1882-1929) - austriacki por. piech. do 1 XI 1912, przydzielony do LP w połowie 1915 r. 1 I 1916 kpt. piech., od stycznia 1917 kom. baonu 6 pp. Kom. pułku po kryzysie przysięgowym do jego rozwiązania, następnie w armii austriackiej. Od 1918 r. w WP w randze rtm., w DOGen. Kielce, potem w MSWojsk. W 1921 r. ppłk tab., 29 II 1924 w st. sp. w stopniu płk. tab. Zob. https://zolnierze-niepodleglosci.pl/\%C5\%BCo\%C5\%82nierz/228166/ (dostęp: 18 IV 2020).

85 Jan Skorobohaty-Jakubowski (do 1916 Jakubowski; 1878-1955). Zob. A.K. Kunert, Skorbohaty-Jakubowski Jan (1878-1955), PSB, t. XXXVIII, Warszawa-Kraków 1997-1998, s. 265-267.

${ }^{86}$ Bronisław Głowiński „Godziemba” (1880-1918) - dyrektor szkoły ludowej, urzędnik bankowy, konstruktor lotniczy. Od 17 X 1914 w LP, por piech. Do maja 1915 r. instruktor w Szkole Podchorążych LP, następnie Komendant placu w Piotrkowie i Komendant Grupy LP do stycznia 1916 r. Potem do maja tego roku ponownie w Szkole Podchorążych, a następnie w 6 pp LP. Ranny pod Kostiuchnówką. 1 XI 1916 kpt. piech., do marca 1917 kom. baonu 6 pp LP. Po kryzysie przysięgowym kierował likwidacją pułku, potem komendant Szkoły Podoficerskiej PKP. Internowany po Rarańczy. Zamordowany w Złoczowie przez Ukraińców 24 XI 1918. Pośmiertnie mjr piech. Zob. https://zolnierze-niepodleglosci.pl/\%C5\%BCo\%C5\%82nierz/191819/ (dostęp: 18 IV 2020). 
autorytet jedynie poprzez bezwzględne i często niesłuszne karanie, przez co wzbudza strach i jest znienawidzony przez oficerów i żołnierzy.

Jego wcześniejsze zapał znacznie osłabł. Rzadko przychodził na służbę i nie zatrzymywał swych oficerów na służbie.

Wobec porad niemieckich oficerów powierzchowny, ale przystępny, intryguje jednak przeciw nim i podburza polskich oficerów.

Jest przewrażliwiony i nieszlachetnego usposobienia.

Uważam kapitana Glowinskiego za niezdatnego do zajmowania stanowiska komendanta batalionu przebudowywanym wojsku.

Stümpf

Kapitan i najstarszy rangą oficer Przy niemieckiej Kom. Wyszkolenia 6. Pol. Pułku piechoty

13

Zał. 2

Niemiecki Kom. Wyszkolenia przy 6. pol. Pułk. Piech.

Dz. nr 8 pers.

Pułkownik brygadier Zielinski ${ }^{87}$, dawny austriacki komendant pułku ${ }^{88}$, jest oficerem, który cieszy się w 6. Pułku wielkim poklaskiem i wysoka sława wśród oficerów i żołnierzy. Posiada dużą popularność w Legionach Polskich, uchodzi za wybornego dowódcę w polu i za człowieka o osobistej odwadze.

Interesuje się przeszkoleniem polskich oddziałów wedle niemieckich wzorów i zdaje się posiadać dobre rozeznanie w sprawach wojskowych, spokój i rozwagę.

$\mathrm{Z}$ powodu ostrej choroby żołądkowej nie jest w dobrej formie fizycznej.

Uważam pułkownika Zielinskiego za odpowiedniego na stanowisko komendanta brygady w przebudowywanym wojsku.

Stümpf

Kapitan i najstarszy ranga oficer Przy niemieckiej Kom. Wyszkolenia 6. Pol. Pułku piechoty

\footnotetext{
${ }^{87}$ Zygmunt Zieliński (1958-1925). Zob. P. Hapanowicz, Generał Zygmunt Zieliński (1858-1925). Szkic do portretu, Kraków 2012.

${ }^{88}$ Od 1 XI 1910 do 11 VI 1911 r. kom. 13 pp z Krakowa.
} 
Komenda Wyszkolenia

1. pol. Pułk. Ułanów

Wg: G.-G. Warszawskie

Inspekcja Wyszkolenia

z 1. III 1917 Dz. nr 89 pers.

Dot. Wyszkolenia 1. p. uł.

\section{Sprawozdanie}

\section{$[\ldots]$}

W pojmowaniu obowiazków służbowych korpus oficerski wymaga jeszcze wychowania. Służba musi być wykonywana przez oficerów jeszcze sprawniej, rzetelniej, staranniej, pod silnym wolą kierownictwem. Przed wszystkim jednak powinni oni starać się bardziej poprzez staranną opieką nad żołnierzami wzbudzić ich przywiązanie, którego następstwem jest sumienność. Z tej wynika dyscyplina, które jest filarem armii i ma związek z każdym sukcesem. Brakuje znacząco niezbędnego podporządkowania wszystkich części ogólnym wytycznym i szczegółowym rozkazom. Drobne aspekty służby są nisko cenione, miast wypełniane z powagą i dokładnościa. Staranność i skrupulatność co do służby wewnętrznej, które w pierwszej linii dają przełożonym do ręki klucz do wpływania na podkomendnych, pozostawiają na równi wiele do życzenia.

Podczas ustnych narad z komendantem pułku przedstawiono mu sprawozdania tygodniowe $\mathrm{z}$ odpowiednimi zaleceniami i propozycjami, dzięki czemu udało się osiagnać, że ze strony przełożonych przeprowadzono ostre kontrole. Choć nadal nie zawsze wszyscy oficerowie stawili się w komplecie do służby, poczucie służby jest i tak wyższe niż w poprzednich tygodniach.

Abstrahując od pojedynczych oficerów, dla których pojęcie poczucia obowiązku wciąż jest pojęciem obcym i które zastępowane jest ich własnym pojmowaniem obowiązków służbowych, większa część z nich po gruntowanym wprowadzeniu w poszczególne gałęzie służby, może z powodzeniem pod właściwym kierownictwem szkolić rekrutów.

v. Stechow ${ }^{89}$ Rotmistrz

\footnotetext{
${ }^{89}$ Alexander von Stechow - rotmistrz od 13 IX 1906 r., 10 Armia, Grupa Eichorna.
} 
Komenda Wyszkolenia

1. pol. Pułk. Ułanów

Wg: G.-G. Warszawskie

Inspekcja Wyszkolenia

z 1. III 1917 Dz. nr 89 pers.

Dot. Oceny majora Beliny

Zdolności wojskowe majora Beliny ${ }^{90}$ sa w tym zakresie trudne do oceny, albowiem w przeciagu 2,5 zimowych miesięcy rzadko pojawiał się w garnizonie, pozostawiając raczej większą część zadań swojemu zastępcy rotmistrzowi Głuchowskiemu ${ }^{91}$.

Major Belina posiada mało gruntownej wiedzy o przepisach wojskowych i wymaganiach odnośnie szkolenia korpusu oficerskiego i żołnierzy.

Chociaż brakuje mu taktu i formy na większość stanowisk, jego pozycja jest bezpieczna i określona. Nie da się czasowo podważyć jego zdolności do dowodzenia pułkiem.

v. Stechow

Rotmistrz i najstarszy oficer

Komendy Wyszkolenia przy

1. polskim Pułku Ułanów

16

Mińsk Mazowiecki, 6/ III 1917

Kom. Wyszkolenia

2. P. Ułanów pol. Legionów

Wg: Dz. nr 89 pers.

\section{Sprawozdanie}

[...]

Odnośnie polskiego korpusu oficerskiego może być wpierw powiedziane, że ten prezentuje się mniej przyzwoicie w porównaniu do podporządkowanych

90 Władysław Belina-Prażmowski (1888-1938). Zob. P. Hubiak, Belina i jego ułani, oprac. not biograficznych K. Stepan, Kraków 2003; P. Stawecki, Prażmowski (Belina Prażmowski) Wtadystaw Zygmunt (1888-1939), PSB, t. XXVII, Wrocław 1984-1985, s. 393-395.

91 Janusz Głuchowski (1888-1964). Zob. https://zolnierze-niepodleglosci.pl/\%C5\%BCo\%C5\%82nierz/191829/ (dostęp: 18 IV 2020). 
mu oddziałów (założono wyjątki). Podobnie źle wypada on przy wciąż niezadowalającym korpusie podoficerskim.

Wprawdzie w wykonywaniu obowiązków służbowych pojawiło się wyższe jego postrzeganie, jednak wciąż pozostaje trochę do życzenia. W tym wypadku mniej brakuje dobrej woli jak czasu, który właściwie wykorzystany, mógłby doprowadzić do pełnej zmiany jego postrzegania. Szczególnie szkodliwa w pułku i poszczególnych szwadronach jest stosunkowo zbyt duża liczba oficerów i podoficerów, których czasowe awanse zdają się częściowo dokonane bez niezbędnych egzaminów i w drodze ich wyboru.

[...]

Zdolność szkolenia rekrutów posiada na stan dzisiejszy ok. połowa oficerów, na podstawie ich rozpoznanej wiedzy i zdolności.

von Breza ${ }^{92}$

Rotmistrz i dowódca Komendy Wyszkolenia przy

2. P. Ułanów

17

Modlin, 8.3.1917

Komenda Wyszkolenia

przy Kompanii Tech.

Pol. Siły Zbrojnej

Dz. nr 6 tajny

Sprawozdanie do Dz. nr 89 pers. z 1. 31917

Poufne

$[\ldots]$

Nastroje w oddziałach.

Oficerowie i żołnierze obu kompanii wykazują zainteresowanie służba, sa chętni i otwarci na każdą naukę, jak też poradę Korpus oficerski jest jednak obecnie w dość smętnym nastroju, widocznym, ponieważ powolne postępy w rozwoju polskiej armii nie są zadowalające. Ich początkowy zapał do służby osłabł nieco z tego powodu.

$[\ldots]$

Postrzeganie służby przez oficerów. Mimo pozornie widocznego zapału niektórym oficerom nadal brakuje niezbędnej wytrwałości i regularności w wypełnianiu swoich obowiązków. W tym kontekście stwierdzono stale wzrastającą poprawę i zauważono starania by poznać niemieckie pojmowanie

${ }^{92}$ Stanisław von Breza - rotmistrz od 1910, z II/241 Rezerwowego pp. 
i poczucie obowiązku. Stale, biorąc pod uwagę cechy Polaków. Wskazówki co do wielkiej odpowiedzialności dowódców wszelkiej rangi i zagrożenia dla dyscypliny powodowanego przez luźne podejście do służby przez przełożonych, zaczynaja jednak wskazywać dobry wpływ.

Szkolenie rekrutów. Podsumowując, można powiedzieć o oficerach kompanii saperów i technicznej, że już teraz są użytecznymi i odpowiednimi instruktorami dla kształcenia rekrutów.

\section{Komendanci}

$\mathrm{Na}$ komendantów kompanii nadają się wedle wykazanej dotąd wiedzy i prezencji przed frontem:

Porucznicy Dąbkowski ${ }^{93}$ i Mozdrzeń [sic! ${ }^{94}$ z kompanii saperów, jak też porucznicy Ciborowski ${ }^{95}$ i Warchałowski ${ }^{96}$ z kompanii technicznej.

${ }_{93}$ Stefan Dabkowski (1884-1962) - absolwent Szkoły Techniczno-Kolejowej w Warszawie. Od 1899 działacz niepodległościowy, od 1902 członek Polskiej Partii Socjalistycznej i Organizacji Bojowej (OB) PPS. Dwukrotnie aresztowany, zesłany na Syberię, skąd zbiegł. Od 1908 r. członek ZWC, następnie ZS. Od sierpnia 1914 r. w LP, kom. plut. i komp. saperów w 1 pp LP, gdzie służył do kryzysu przysięgowego. Od 9 X 1914 r. ppor. sap., od 1 I 1917 por. sap. Internowany w Beniaminowie, od marca 1918 r. w szeregach POW we Lwowie. Od stycznia do maja 1919 więziony przez Ukraińców. Następnie w WP, kierownik fortyfikacji linii Wisły. Po wojnie polsko-bolszewickiej ppłk saperów, dow. 10 psap, szef Wydziału Saperów w MSWojsk. (1926-1927). Od 1 I 1928 r. płk sap., 30 IV 1934 w st. sp. Senator dwóch kadencji, wicemarszałek senatu. W 1939 r. przedostał się do Rumunii i dalej na Bliski Wschód. Zmarł w Londynie. Zob. https://zolnierze-niepodleglosci.pl/\%C5\%BCo\%C5\%82nierz/187553/ (dostęp: 18 IV 2020).

${ }^{94}$ Kazimierz Możdżeń (1883-1946) - w latach 1904-1908 student Politechniki Lwowskiej. Członek OB PPS, ZWC i ZS. Od sierpnia 1914 r. w LP, przydzielony do 1 komp. sap. 5 III 1916 r. ppor. sap. i kom. plut. Od 1 I 1917 por. sap., służył m.in. w 6 pp LP. Po kryzysie przysięgowym internowany w Beniaminowie. Od listopada 1918 w WP, kolejno dow. baonu, Szef Saperów Frontu Wołyńskiego. 21 VIII 1919 przydzielony do Inspektoratu Inżynierii i Saperów, dow. baonu w Obozie Szkolnym (1919-1921). Po wojnie polsko-bolszewickiej ppłk sap., m.in. p.o. dow. 4 psap, referent w kierownictwie fortyfikacji Obozu Warownego „Wilno”, od 1927 kierownik fortyfikacji Obozu Warownego „Ślask”. Następnie kierownik działu w Wytwórni Amunicji nr 2 w Rembertowie. Od 29 II 1932 w st. sp. Po kampanii 1939 r. przedostał się na Zachód, przydzielony do Wojskowego Instytutu Technicznego w Londynie. Zob. https://zolnierze-niepodleglosci.pl/\%C5\%BCo\%C5\%82nierz/210359/ (dostęp: 18 IV 2020).

95 Roman Ciborowski (1884-1963) - członek PPS i OB PPS. Aresztowany, więziony w Sieradzu, skazany na zsyłkę, z której zbiegł. Student medycyny na UJ. Od sierpnia 1914 r. w LP, w komp. narciarskiej, następnie w komp. tech. 4 pp. Od 20 V 1915 ppor., a od 1 VII 1916 por. sap. Uczestnik bitwy pod Kostiuchnówka. Następnie w 6 pp i 2 Kompanii Saperskiej Technicznej Komendy LP. Po kryzysie przysięgowym pozostał w PW. Od 30 VIII 1917 r. kpt. sap., dow. Kursu Wyszkolenia Saperów i 1 komp. sap. PW. Uczestnik walk w Małopolsce Wschodniej w 1919 r., następnie dow. baonu sap. Od 1 IV 1920 mjr sap., po wojnie zweryfikowany w stopniu ppłk. sap. W latach 1921-1928 dow. 1 psap, następnie szef Wydziału Saperów w Departamencie Inżynieryjnym MSWojsk. Od kwietnia 1929 dow. I Brygady Saperów, 1 I 1930 r. w stopniu płk. sap. 31 VIII 1934 w st. sp. Zmobilizowany w 1939 r., przez Rumunię przedostał się na Bliski Wschód, gdzie służył do 1944, gdy przeniesiono go w stan nieczynny. Zmarł w Londynie. Zob. https://zolnierze-niepodleglosci. pl/\%C5\%BCo\%C5\%82nierz/186337/ (dostęp: 18 IV 2020).

96 Józef Warchałowski (1877-1920) - inżynier, działacz niepodległościowy. Od sierpnia 1914 r. w Legionach, w II Baonie Uzupełniającym i komp. sap. przy Komendzie LP. 11 XI 
Kapitanowie Hellman ${ }^{97}$ i Dąbkowski ${ }^{98}$ zaliczają się do osobowości, które jak można założyć, posiadają zdolności, które czynią ich odpowiednimi do dowodzenia batalionem w wystawianej armii.

Laudowicz $^{99}$

Kapitan

1915 chor. sap., 1 VII 1916 ppor. sap. Od 1917 w Kompanii Saperskiej nr 2 Technicznej Komendy LP. Po kryzysie przysięgowym w PW, przydzielony do 1 pp PW. 12 X 1918 Rada Regencyjna zatwierdziła go w stopniu kpt. piech. Służył w 7 pp. Leg. Zmarł w trakcie służby na froncie ukraińskim, pośmiertnie mjr piech. Zob. https://zolnierze-niepodleglosci. pl/\%C5\%BCo\%C5\%82nierz/230276/ (dostęp: 18 IV 2020).

97 Włodzimierz Hellman (1880-1964) - student Szkoły Mechaniczno-Technicznej im. H. Wawelberga i S. Rotwanda w Warszawie. Od 1904 działacz PPS i OB PPS, brał udział w produkcji bomb. Instruktor kursów bojowych. Uczestnik akcji ekspropriacyjnych, w tym w akcji pod Bezdanami 28 IX 1908 r. Aresztowany w 1909 r., rok później zwolniony, wyjechał do Galicji. Działacz Wydziału Bojowego PPS do 1911, przeciwnik emancypacji ZWC. Od sierpnia 1914 r. w LP. 9 VIII 1915 r. por., 1 VII 1916 kpt. sap. Od marca 1916 r. kom. komp. techn. LP. Po kryzysie przysięgowym mjr, pozostał w PKP. Internowany po Rarańczy. Od maja 1918 r. w szeregach PW, a od listopada tego roku w WP. Uczestnik wojny polsko-bolszewickiej, m.in. dow. 101 Rezerwowego Pułku Piechoty Dywizji Ochotniczej (później 84 pp). Po wojnie awansowany na ppłk., na własną prośbę przeniesiony w marcu $1924 \mathrm{r}$. w st. sp., z przydziałem do dotychczasowego pułku, przewidziany do służby w czasie wojny. Pracownik Zakładów Amunicyjnych „Pocisk” i Instytutu Technicznego Uzbrojenia MSWojsk. W 1939 ewakuowany na Węgry, następnie we Francji i Anglii, przeniesiony w st. sp. 1 IV 1944 r. szef Komisji Kontrolnej Gospodarki Pieniężnej Funduszem Specjalnym, w 1945 r. powrócił do Warszawy. Stownik biograficzny działaczy polskiego ruchu robotniczego, t. II, red. nacz. F. Tych, Warszawa 1987, s. 500-501.

98 Mieczysław Dąbkowski (1880-1946). Zob. W. Kozłowski, Generał Mieczysław Dabkowski, zwierzchnik piotrkowskich piechurów 1926-1933. Zarys biografii, „Rocznik Łódzki” 1996, t. XLIII, s. 167-188.

${ }^{99}$ Mieczysław Laudowicz (1878-1927) - kpt. od 22 V 1915 r., poprzedni przydział 1 Wschodniopruski Batalion Pionierów. Po wojnie w szeregach WP, m.in. szef Inżynierii i Saperów DOK VII w Poznaniu w stopniu ppłk. (1921-1926). 